\title{
EFFECT OF A DIFFUSER TOWER ON THE POWER OUTPUT OF A SOLAR CHIMNEY POWER PLANT
}

\author{
Pranav S. Sawant ${ }^{1}$, Aniket A. Gor ${ }^{2}$ \\ ${ }^{1,2}$ B.E Student, Department of Mechanical Engineering, K.J Somaiya College of Engineering, Maharashtra, India
}

\begin{abstract}
The present paper has discussed about the effect of the diffuser tower instead of the conventional cylindrical tower on the power output of the Manzeneres Solar Chimney Power Plant. The power output of the plant has been estimated if the diffuser tower would have been implemented. For implementing the draft in the tower the use of adifferent structure is proposed instead of the sheet steel ring structure.
\end{abstract}

Keywords: Solar Chimney, Diffuser Tower, Solar Updraft Tower, Draft Angle.

$* * *$

\section{INTRODUCTION}

A Solar Updraft Tower is a combination of basic principles such as the greenhouse effect, the chimney effect and wind turbines for generation of electricity from solar radiation. Specific fractions of direct and diffuse solar radiation that strikes the glass roof are reflected, absorbed and transmitted. The solar incidence angle and optical characteristics of the collector material influence the quantities of these specific fractions [1]. Multiple reflection and absorption of the solar radiation between the ground and the collector roof causes the air between them to heat up. This warm air rises inside the chimney due to the pressure difference between the chimney base and the chimney outlet. Buoyant air rises in the chimney which draws in more air from the collector perimeter. The kinetic energy of the collector air which flows across the turbine turns the turbine blades to drive the generator to generate electricity [2]. The Figure [1] shows the working of a typical Solar Chimney Power Plant.

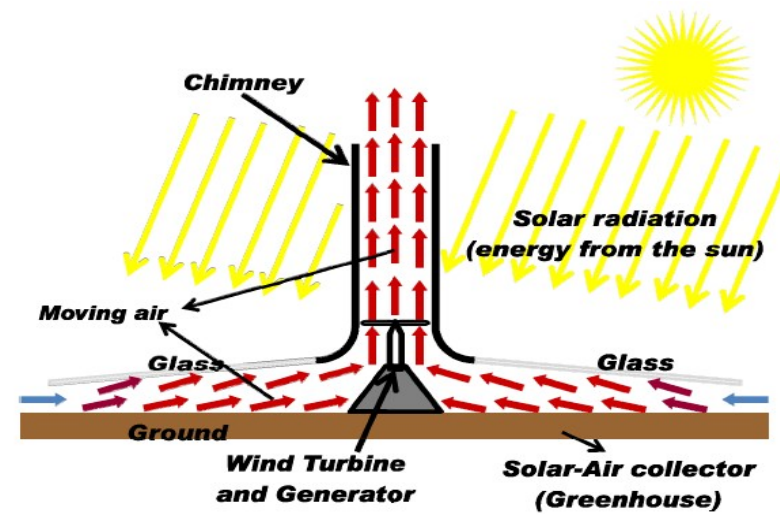

Fig -1:Schematic of a Solar Chimney Power Plant

Various performance enhancement techniques were applied over the years to increase the power output of the plant and this paper discusses one such technique proposed by Shinsuke Okada which states about the effect of the diffuser tower instead of a cylindrical tower on the power output of a Solar Chimney Power Plant (SCPP) [3]. This paper discusses about the power output which can be predicted using his theory for the SCPP in Manzaneres, Spain.

\section{THE PROTOTYPE IN SPAIN}

The SCPP in Manzaneres, Spain was the first SCPP ever built which demonstrated its technical feasibility for electricity generation. It was designed by Schlaich Bergermann and had a collector radius of $122 \mathrm{~m}$ and a tower 193 meters tall with a radius of 5.03 meters. The temperature difference attained in the collector was around $20^{\circ} \mathrm{C}$. This plant generated an output of $50 \mathrm{~kW}[4,5]$. The chimney was made of sheet steel rings as shown in Figure [2] which worked for eight years until the chimney tower support wires rusted and the chimney was blown over by the storm [1].

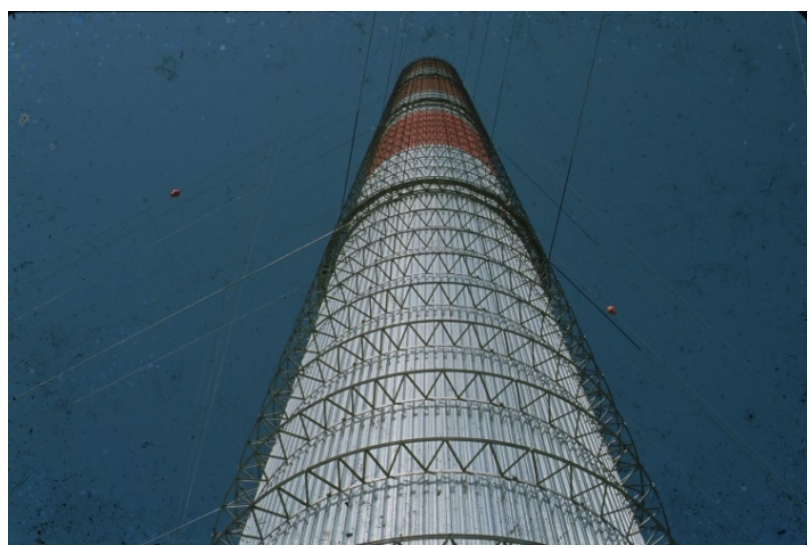

Fig -2: The Chimney in Manzaneres, Spain made of sheet steel rings supported by guyed wires

We will discuss about the power output of the plant whose tower is constructed using reinforced concrete [suggested by Schlaich (1994) for high towers] integrated with a draft angle of $4^{\circ}$ as shown in Figure [3] with all other dimensions kept constant as that of the prototype discussed above. Such a diffusion tower will require enough support and thus a rib structure is proposed to strengthen the tower as shown in Figure [4]. 

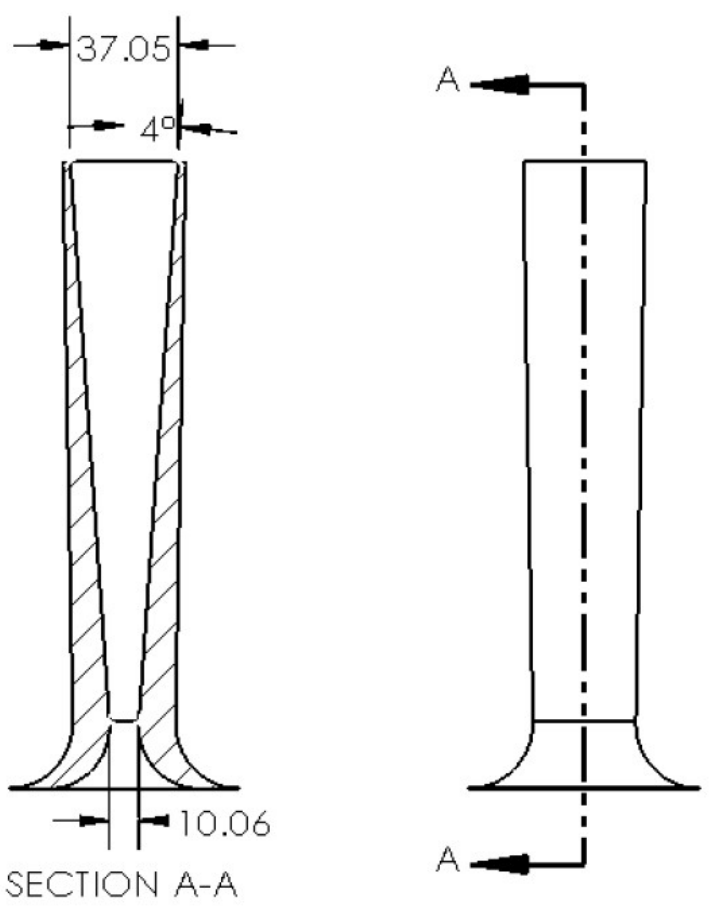

Fig -3: Proposed solar Chimney with a draft angle of $4^{\circ}$ made of concrete

\section{EFFECT OF DIFFUSER TOWER ON THE POWER OUTPUT}

Shinsuke Okada (2015) investigated the effect of the diffuser on the solar chimney structure and stated that the inner diameter of the tower expands as the height increases so that the static pressure recovery effect of the diffuser causes a low static pressure region to form at the bottom of the tower which induces greater airflow in the tower [3]. After conducting their laboratory experiment and the CFD analysis of the laboratory sized model they came to the conclusion that the velocity induced by a diffuser type tower is 1.38-1.44 times greater than the conventional cylindrical type tower. As the power output is proportional to the cube of the incoming velocity, it can be expected to be approximately 2.6-3.0 times greater than the conventional cylindrical tower design [3].

Using the conclusions of the theory stated above we can say that by implementing a diffuser tower the new power which can be extracted from the system can be given by

$\mathrm{P}_{\text {diff }}=2.8 * \mathrm{P}$

Where $\mathrm{P}_{\text {diff }}$ is the power output with a diffuser type tower and $\mathrm{P}$ is the power output with a conventional cylindrical tower.

As the the power generated by the Manzaneres plant was $50 \mathrm{kw}, \mathrm{P}_{\text {diff }}$ can be calculated using (1),
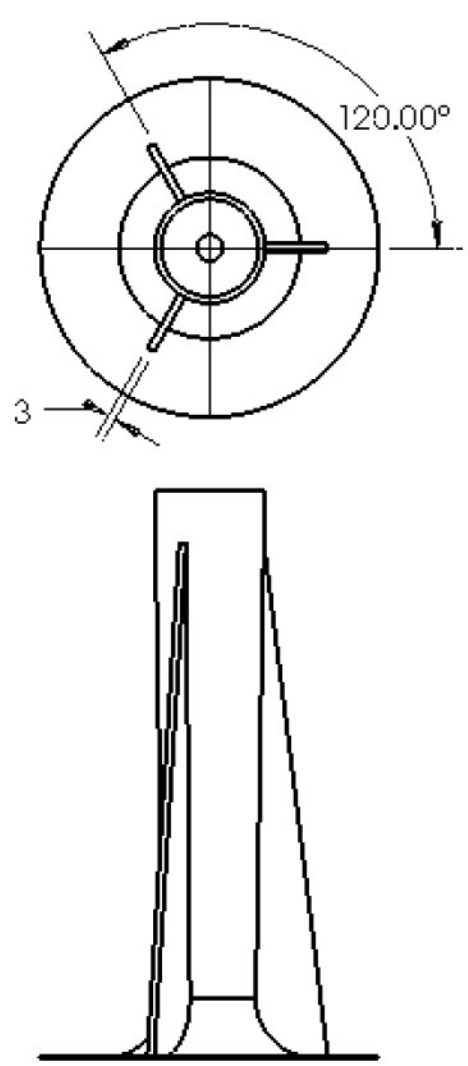

Fig -4: Rib structure for strengthening the tower

It can also be observed that the same power output of the Manzaneres plant can be achieved by using a shorter tower. As the power output of the SCPP is directly proportional to the collector area and the tower height [6] we can write the following equations,

$\mathrm{P} \propto \mathrm{A} * \mathrm{~h}$

Where $\mathrm{A}$ is the area of the collector and $\mathrm{h}$ is the height of the chimney in the Manzaneres prototype.

Now $\mathrm{P} / 2.8$ will give us the power which will be generated by the plant with a smaller height $\left(\mathrm{h}_{\text {small }}\right)$ and all other values equal to that of the Manzaneres plant. But when this smaller tower is replaced by diffuser tower it will generate the same power as that of the Manzaneres plant. We can write the similar equation for the plant with a smaller tower,

$\mathrm{P} / 2.8 \propto \mathrm{A}^{*} \mathrm{~h}_{\text {small }}$

Dividing both the equations we get,

$\mathrm{h}_{\text {small }}=\mathrm{h} / 2.8$

Where $\mathrm{h}=193 \mathrm{~m}$, therefore the value of $\mathrm{h}_{\text {small }}=69 \mathrm{~m}$

The results have been tabulated below

$\mathrm{P}_{\text {diff }}=2.8 * 50=140 \mathrm{~kW}$ 
Table -1: Comparison of $\mathrm{P}_{\text {diff }}$ and $\mathrm{P}$ for two different tower heights

\begin{tabular}{|c|c|c|}
\hline $\begin{array}{c}\text { Height } \\
\text { in meters }\end{array}$ & $\begin{array}{c}\mathrm{P} \\
\text { in } \mathrm{kW}\end{array}$ & $\begin{array}{c}\mathrm{P}_{\text {diff }} \\
\text { in } \mathrm{kW}\end{array}$ \\
\hline 193 & 50 & 140 \\
\hline 69 & 18 & 50 \\
\hline
\end{tabular}

\section{CONCLUSION}

The effect of the diffuser tower instead of the conventional cylindrical tower on the power output of the Manzeneres plant was discussed in the paper. If the diffuser tower would have been implemented instead of the cylindrical tower of height $193 \mathrm{~m}$ then the power output of the plant would have been $140 \mathrm{~kW}$. The same power output of $50 \mathrm{~kW}$ for the plant could have been achieved if the diffuser tower of $69 \mathrm{~m}$ would have been set up instead of the cylindrical tower of $193 \mathrm{~m}$. For implementing the draft in the tower the use of reinforced concrete supported by the rib structure was proposed instead of the sheet steel ring structure. Though it will be costlier it can be justified by the increase in power output which was discussed in this paper.

\section{REFERENCES}

[1]. Amel Dhahri and Ahmed Omri, "A Review of solar Chimney Power Generation Technology" in International Journal of Engineering and Advanced Technology (IJEAT) ISSN: 2249 - 8958, Volume-2, Issue-3, February 2013.

[2]. T. W. Von Backström, R. Harte, R. Höffer, W. B. Krätzig, D. G. Kröger, H.-J. Niemann, and G. P. a. G. Van Zijl, "State and Recent Advances in Research and Design of Solar Chimney Power Plant Technology," VGB powertech, vol. 88, no 7, 2008, pp.64-71.

[3]. Shinsuke Okada, Takanori Uchida, Takashi Karasudani and Yuji Ohya, "Improvement in Solar Chimney Power Generation by Using a Diffuser Tower" in Journal of Solar Energy Engineering, Vol. 137 / 031009-1, June 2015.

[4]. J. Schlaich, Solar Chimney: Electricity from the Sun. Stuttgart; Edition Axel Menges, p.16,1995.

[5]. S. Quraeshi, "Solar/wind power plants" Solar\&amp; Wind Technology, no 1, pp. 51-54.

[6]. J. Schlaich, R. Bergermann, W. Schiel, and G. Weinrebe, "Design of Commercial Solar Updraft Tower Systems-Utilization of Solar Induced Convective Flows for Power Generation," Journal of Solar Energy Engineering, vol. 127, no 1, p. 117, 2005

\section{BIOGRAPHIES}



\section{PranavS. Sawant,}

BE Student,

Dept. of Mechanical Engineering,

K.J Somaiya College of Engineering.

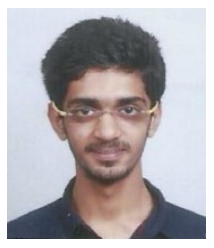

Aniket A. Gor

BE Student,

Dept. of Mechanical Engineering,

K.J Somaiya College of Engineering. 